\title{
Managerial Skills, Financial Capability and Strategic Planning in Organizations
}

\author{
Vincent Bagire ${ }^{1}$, Juliana Namada ${ }^{2}$ \\ ${ }^{1}$ Department of Business Administration, Makerere University Business School, Kampala, Uganda; ${ }^{2}$ Department of Business Ad- \\ ministration, School of Business, University of Nairobi, Nairobi, Kenya. \\ Email: bagirev@yahoo.com,juliesimonis@yahoo.com
}

Received June $21^{\text {st }}, 2013$; revised July $21^{\text {st }}, 2013$; accepted August $9^{\text {th }}, 2013$

Copyright (C) 2013 Vincent Bagire, Juliana Namada. This is an open access article distributed under the Creative Commons Attribution License, which permits unrestricted use, distribution, and reproduction in any medium, provided the original work is properly cited.

\begin{abstract}
This study sought to establish the relationship between managerial skills, financial capability and the level of strategic planning. The study was premised on the increasing focus on strategic planning in Ugandan organizations. There was however, a lack of local empirical studies on the factors driving this trend. Data were obtained from organizations in various sectors that included government institutions, private and family business organizations. The findings confirmed that organizations were involved in significant level of strategic planning. There was a positive and significant relationship with managerial skills. However, there was a very weak relationship with the financial capability. The implication of the findings for management was to give more attention to managerial skills to ensure congruence of operations.
\end{abstract}

Keywords: Strategy; Managerial Skills; Strategic Planning; Financial Capability; Environment

\section{Introduction}

Studies on various perspectives of strategic management are still in nascent stages in many developing countries. Strategic planning has become a key activity for many organizations in the third world. Businesses have gone through various turbulent times orchestrated mainly by the dynamic external environment. This is attributable to others, policies of liberalization and globalization that have triggered vibrancy in the business sector. Many national enterprises have sprung up alongside the entry of multinationals into various sectors. The non-profit sector in many countries has also developed rapidly with institutions like schools, medical centres and nongovernmental organizations become key economic actors. This business landscape has led to improvement in management practices. There is still a low level of adoption of various perspectives of strategic management in many African economies [1]. Even through organizations are involved in strategic planning and other strategic contingencies, there is inadequate empirical knowledge on how organizations are operating. In Uganda, the level and magnitude of strategic planning practices in local organizations have not been studied. The interest of this study was therefore to examine the influence of manage- rial skills and financial capability as possible precursors to the level of strategic planning in organizations. The results would inform both scholars and practitioners in Uganda particularly about strategic management practices.

\section{Literature Review}

\subsection{Strategy and Strategic Planning}

Strategy is a multidimensional concept. The term strategy has been used variously by different people. Some scholars view strategy as a means to an end, others view it as a unifying tool while others still consider it as a link between the firm and its environment. Sometimes it has been confused with goals. According to [2], the many definitions are in some ways exclusive but mutually supportive. Reference [3] on the one hand defined strategy as a pattern of a stream of decisions. Reference [4] postulated that strategy is about positioning a business in a given industry through an analytical process. According to [5] strategy is the direction and scope of an organization over the long term. It achieves advantage for the organization through its configuration of resources within a changing environment. A well formulated strategy should meet the needs of markets and fulfill expectations of stakeholders. Strategy consists of the means an organiza- 
tion chooses to move from its present state to its future. It can be planned or emergent.

Conversely, strategic planning is an organizational road map that specifies long term strategic options. It is a rational, normative and a deliberate process where ends are specified first followed by means [6-8]. Strategic decision making is at the heart of both business policy literature and organizational theory literature. Reference [9] defined strategic planning as the decisions that organisations undertake to align with the organizational environment. This process mainly involves setting the vision and mission, scanning the environment, formulation, implementation and evaluation of strategies. Reference [10] articulated that organisations must have a commitment of financial and human resources, policies and a reward system if strategic planning is to bring desired results. Reference [11] elaborated this point of departure that managerial performance which is a measure of success in strategic planning is an efficacy of managerial action. Reference [12] posited that strategy exists in the mind of managers, in their company theory and also embodied in firm routines and rules. Strategic planning is therefore one distinctive process of articulating strategy. However, there are many disturbances that strategic planning faces in light of the environment. There are forces contained in both the internal and external factors that influence and impact upon the process. These include management system, structure, resource, government and other industrial forces. The strategic planning process involves managers undertaking continuous strategic decision making to align the organization to its changing environment.

\subsection{Strategy Formulation, Implementation and Evaluation}

The unpalatable questions to researchers that have continued in the area of strategy are how to formulate strategic plans that are responsive to the environment, the distinctive internal and external factors that influence this process and how to take full advantage of resources. Strategic planning process involves continuously making strategic decisions that direct the organization into its future. This requires making choices that lead to action, implementation of strategy and evaluation. Strategic planning was explained as a moving target, more of an art than a science and a province of top management [13]. Strategy formulation requires testing of the premises on which the organization is operating. Improved analysis of scenarios stimulates wide ranging strategy formulation possibilities that eventually enhance implementation and evaluation. Real strategists immerse in detail of daily nuggets and top managers are at times in abstract. Patience as a managerial value is emphasized and notably that strategy formulation takes time [14].
Implementation on the other hand involves putting strategies and policies into action through programs, budgets and procedures. The separation of strategy formulation and strategy implementation has been one of the pains of understanding strategic management. Earlier authors posited in their classical writing that this distinction was never clear [15]. They noted that separation was for pedagogical value only. Subsequent scholars have argued that the two are interdependent and managers must understand the general tasks in both. Another interrelated confusion arose between strategic planning and strategy formulation $[16,17]$. Execution of strategy should be seen as an organizational process. Effective strategy implementation leads to effective outcomes, leading to capabilities for better strategy formulation ideas [18].

Strategy evaluation and control is the process of monitoring corporate activities and performance results so that actual performance can be compared with desired performance. Reference [19] developed an argument that takes managers beyond the obvious of checking how business is performing. He added that the final system of strategy evaluation can be explosive. Strategy evaluation has remained elusive to some researchers on strategy. Reference [20] developed the double loop framework of strategic management in which they underpin the link between strategy formulation and evaluation. A good strategy does not need constant reformulation; most managers would be hurt rather than helped to have the validity of their basic missions called into question on regular basis. Managers need to maintain a dual activity view of strategy formulation, implementation and evaluation.

\subsection{Managerial Skills}

A study by [21] concluded that managerial cognition drives strategic action. Given the continued debate of what strategy really is and how it is formulated [12] it turns to the skills of the manager to shape what he takes to be a strategy and what to be pursued as goals. Management skill and relationship with other factors in the organization are fundamental and it was argued that managerial skill was a strategic resource [22]. Earlier scholars in strategic management have emphasized the role of executive leadership in strategic management decisions [23]. The emphasis today is to understand the values, background, experience and skills of top managers and how they shape the thinking of the organization in developing strategic plans. It was argued that strategic choices and performance are associated with characteristics of top management [24]. It is concluded that an organization is a reflection of its top echelons. The fundamental tenets of strategic management that premise the success of top managers in this process are consistence, consonance and feasibility [25]. In another grounded study scholars ana- 
lyzed 2125 articles in five strategic management journals between 1980 and 2005 from which a strategy mapping was developed indicating that leadership, decision making, cognitive ability and methodology were strong competencies in management's role to achieve a strategic fit [26].

\subsection{Financial Capability}

There is less emphasis of financial capability in empirical studies on various strategic management perspectives. Financial capability was identified by [26] as a strong fit in corporate level strategy. Various researchers on strategy implementation recognize the need for financial resources. It is however inadequately articulated whether the strategist should assess the financial capability to implement strategic plans before formulating the strategy. It is from these linkages that financial capability was enumerated as a precursor to strategic decisions hence influencing the level of effectiveness. Reference [20] was possibly more expressive on the financial perspective in strategic management. It was emphasized that timely and accurate funding data was a priority in relation to other perspectives of the balanced score card of translating strategy into action. Many studies have only focused on financial capacity as a dependent variable to strategic elements and less as a determining factor to the strategic planning process. However, many scholars of the resource based view recognize the importance of both tangible and intangible resources for the success of strategic planning in organizations. Firms need financial and managerial resources to improve productivity [27].

\subsection{Moderating Factors}

- According to empirical studies the environment selects various organizational forms. In the external environment government is a force to reckon with; it acts as tax levy, regulator, customer, partner and banker. Other moderating factors could be industrial forces including competitors and their actions, new products, and industry trends. Another important element today in the environment is technology.

- Most successful organizations are in the fore front of technological innovation [28] while [29] emphasized that managers should essentially forecast future technological turbulence, diagnose organization's present aggressiveness, determine future technology gaps and design action for the future innovations and adaptations.

- To succeed today general managers must have the mindset and skills to interpret the direction the environment is taking as this will affect the financial capability of the organization directly or indirectly. This will in essence influence the level and content of strategic plans.

In light of the debate in extant literature and the Ugandan business landscape, the following hypotheses were formulated to guide this study.

H1. There is no evidence that organizations are involved significantly in strategic planning.

$\mathrm{H} 2$. There is no significant relationship between managerial skills and strategic planning in organizations.

H3. There is no significant influence of the financial capability to Strategic planning .

H4. There is no significant joint relationship between managerial skills and financial capability and strategic planning in organizations.

\section{Methodology}

This study adopted an analytical cross sectional design. Since the drive was to seek views on the strategic planning processes among Ugandan organizations, a survey population was satisfactory. This study used a population of managers on an executive development course. The use of managers on a study program in surveys has been found enriching in previous studies with successful outcomes [30,31].

The student managers were from different organizations both in public and private sectors. From a total of 300 , a sample of 169 was taken basing on tables developed by [32]. A total of 78 questionnaires were received back giving a response rate of $46.1 \%$. However after initial sorting and checking for completeness and missing cases, only 60 questionnaires were used in the analysis giving $35.5 \%$ of the sample.

\section{Results}

\subsection{Respondent Characteristics}

The highest response came from respondents working in the government civil service at $43.3 \%$, followed by those in corporations which nearly tied with private firms with $28.3 \%$ and $26.7 \%$ of the respondents, respectively. There was only 1 repondent employed in family business. In terms of size by number of employees, $70 \%$ of the organizations had numbers above 100 . The respondents who had worked for $2-5$ years were the majority at $78.3 \%$ as against $15 \%$ who had worked in those organizations for more than 5 years. Meanwhile in all the 60 cases, $10 \%$ were in top management positions, $38.3 \%$ in supervisory roles while $50 \%$ were at operational level of management. This distribution was good to provide insights of perceptions from different levels of the organisation. The results therefore reflected non biased responses which were not skewed to any level of management, sector and length of service among the respondents. 


\subsection{The Variables in Strategic Planning}

This objective was achieved using descriptive statistics and testing of hypothesis H1.

The results of the descriptive statistics reflected views on several items seeking to know if organizations had strategic plans, how mission and vision were derived, activities in strategy implementation and evaluation. Organizations in $85 \%$ of the respondents had a vision and mission statements; in $73 \%$ strategic planning was done annually while in $67 \%$ strategic planning was done at departmental level. Views on the level of each of the components of the strategic planning processes were interesting. For instance in $52 \%$ cases top management developed the vision and mission, 23\% indicated the contrary view while $25 \%$ were uncertain of how the vision and mission came to be.

In only $7 \%$ was it indicated that strategic plans were developed by external consultants. Regarding how known across the organization the vision and mission are, the affirmative was in $50 \%$ of the responses while $50 \%$ indicated the contrary. In $55 \%$ of the cases, strategic plans were implemented at the departmental level. There was consistency in the evaluation of strategies; in only $8 \%$ cases was it done by external consultants agreeing with the earlier view on formulation of the plans.

But in $58 \%$ of the organizations there was a policy on evaluation of strategic plans, consistent with $70 \%$ periodical reviews earlier analysed, $62 \%$ evaluation was done by top management and extreme $13 \%$ where strategic plans had never been reviewed.

We run correlation analysis to ascertain the degree and direction of the associations among the study variables. The results are presented in Table 1 .

We established that the study variables had positive correlation coefficients. Managerial skill was highly correlated with level of strategic planning; but among the

Table 1. Correlations among the variables.

\begin{tabular}{lccccr}
\hline & 1 & 2 & 3 & 4 & 5 \\
\hline 1) Managerial skills & & & & & \\
2) Financial capacity & $0.427^{* *}$ & & & & \\
3) Strategy Formulation & $0.443^{* *}$ & $0.325^{*}$ & & & \\
4) Strategy Implementation & $0.634^{* *}$ & 0.169 & $0.380^{* *}$ & & \\
5) Strategy Evaluation & $0.572^{* *}$ & $0.297^{*}$ & $0.538^{* *}$ & $0.598^{* *}$ & 0.00 \\
6) Level of Strategic planning & $0.630^{* *}$ & $0.351^{*}$ & & & \\
\hline
\end{tabular}

${ }^{* *}$ Correlation is significant at the 0.01 level (2-tailed); ${ }^{*}$ Correlation is significant at the 0.05 level (2-tailed). composite variables it was more correlated with implementation coefficient of 0.634 significant at 0.01 ; the coefficient was moderate with strategy evaluation and lowest with formulation. Financial capability had a moderately low correlation with level of strategic planning at 0.351 ; with the sub-variables of strategic planning, financial capability had low coefficients with formulation and evaluation and a non significant one with implementation. These correlations provided us with the insight to proceed with the testing of the hypotheses.

\subsection{Testing of Hypothesis 1-Evidences of Strategic Planning in Organizations}

With the descriptive statistics supporting that there is a moderately high level of strategic planning in Ugandan organizations, we proceeded to test for the hypothesis to confirm these results.

H1. There is no evidence that organizations are involved significantly in strategic planning.

Testing H1 was done through analysis of the items which provided evidence that organizations were involved in some level of strategic planning.

The change statistics results are presented in Table 2. The results showed that factors that operationalized strategic planning in this study led to a variation of $73.2 \%$ in Ugandan organizations. The remaining $27 \%$ was due to other factors not revealed in this model and accounted for by the error term. Therefore the model had a very strong fit.

We then used the p-value to test the hypothesis.

Significance level: 0.05\% (95\%).

Decision Rule: Reject the $\mathrm{H}$ if the p-value is less than 0.05 .

$\mathrm{P}$ value is 0.003 , less than 0.05 .

Therefore we reject the statistical hypothesis, H1. The results showed that there is evidence that organizations in Uganda are involved in a significant level of strategic planning.

\subsection{Testing of H2-Managerial Skills and Level of Strategic Planning}

Having confirmed that there was evidence of significant strategic planning we proceeded to examine its relationship with managerial skills.

$\mathrm{H} 2$ tested for this relationship using coefficient of determination and $\mathrm{p}$-value. The results are found in Table $\mathbf{3}$.

Table 2. Model 1: summary for predictors of strategic planning in organizations.

\begin{tabular}{|c|c|c|c|c|c|c|c|c|}
\hline \multirow{2}{*}{$\mathrm{R}$} & \multirow{2}{*}{ R Square } & \multirow{2}{*}{ Adjusted R Square } & \multirow{2}{*}{ Std. Error of the Estimate } & \multicolumn{5}{|c|}{ Change Statistics } \\
\hline & & & & R Square Change & F Change & df1 & $\mathrm{df} 2$ & Sig. F Change \\
\hline $0.856^{\mathrm{a}}$ & 0.732 & 0.522 & 6.712 & 0.732 & 3.491 & 18 & 23 & 0.003 \\
\hline
\end{tabular}

${ }^{a}$ Predictors: (Constant), Activities of strategy formulation, implementation and evaluation; ${ }^{b}$ Dependent Variable: Level of Strategic planning. 
The $\mathrm{R}^{2}$ of managerial skills and strategic planning was 0.448 . This meant that managerial skills accounted for $44.8 \%$ of the variations in level of strategic planning. The remaining $54.2 \%$ was not accounted for and therefore attributed to other factors not in this model. This was a moderate linear model. We concluded that there are other stronger factors that would predict level of strategic planning other than managerial skills.

The p-value was established at 0.000 at the 0.05 level of significance. Using the decision rule to negate the hypothesis if the $\mathrm{p}$-value was more than $0.05, \mathrm{H} 2$ was rejected. There was a significant relationship between managerial skills and strategic planning in the organizations.

\subsection{Financial Capability and Strategic Planning}

In $53 \%$ of the cases, respondents indicated that organizations had special budget lines for strategic planning, with $49 \%$ reconfirming that availability of funds was a key factor for strategic planning. In $35 \%$ of the responses, departments awaited funds to implement strategies against $33 \%$ where funds availability was not a key prerequisite.

Majority responses viewed the lack of funds as the key factor that frustrated strategic planning indicated by $54 \%$ for formulation, $66 \%$ for implementation and $43 \%$ for evaluation.

Our empirical test revealed a positive correlation coefficient of 0.351 between the financial capability of organizations and strategic planning. To find out the effect of variation in the level of strategic planning caused by financial capability, we ran a linear regression. The results indicated an $\mathrm{R}^{2}=0.123$, meaning that the model fit of financial capability and strategic planning was very weak.

We proceeded to test for $\mathrm{H} 3$ using standardized coefficient and the z-statistic. The results are summarized in Tables 4 and 5.

The results showed that managerial skills and financial capability jointly account for $40.2 \%$ of the variation in strategic planning in Uganda. The rest of $59.8 \%$ is ex

Table 3. Model 2: summary for managerial skills.

\begin{tabular}{cccc}
\hline $\mathrm{R}$ & $\mathrm{R}^{2}$ & Adjusted $\mathrm{R}^{2}$ & Std. Error of the Estimate \\
\hline $0.670^{\mathrm{a}}$ & 0.448 & 0.438 & 6.442 \\
\hline
\end{tabular}

plained by factors not in our model and accounted for by the error term. We tested $\mathrm{H} 4$ to establish whether the joint effect was significant or not. Using the F-change of 0.000 which is less than the 0.05 level of significance, $\mathrm{H} 4$ was rejected. We conclude that managerial skills and financial capability had a significant joint effect to the level of strategic planning in organizations.

H3 was accepted meaning that financial capability does not significantly influence the level of strategic planning in Ugandan organizations.

\subsection{Discussion, Conclusion and Management Implications}

Our results confirm that Ugandan organizations are significantly involved in strategic planning. We evaluated strategic planning from the perspective of the three subvariables, namely, strategy formulation, implementation and evaluation. Previous studies have confirmed the argument that strategic planning produces better alignment than trial and error learning [33]. However, [34,35] have argued that more attention has been put on the process rather than strategic planning systems.

By evaluating the level of strategic planning and how it integrates with management we extend this line thought. The descriptive results indicate that though the level is significant, it is not system-wide and not well articulated. The responses agree with the literature that the vision and mission are articulated by top management but should be known by all staff and integrate in the work system of the organization.

Our findings reveal low knowledge of the mission and vision among staff and less integration in work processes. The confirmation that external consultants are not used in developing strategic plans nor involved in evaluation revealed that strategic planning is considered an internal function. The inference is that as an internal management activity, it handles with the structures of the organization.

Organizations should build internal managerial capacity to undertake strategic planning and don't rely on external skills. Management participation has been found necessary for organizational performance but needs to be integrated across the organizational structures for effectiveness $[34,36]$.

Table 4. Financial capability and strategic planning.

\begin{tabular}{|c|c|c|c|}
\hline Hypothesis & $\begin{array}{c}\text { Z Statistic } \\
\text { (calculated value) }\end{array}$ & $\begin{array}{l}\mathrm{N}>30 \\
\text { use } \mathrm{Z} \text { test }\end{array}$ & $\begin{array}{l}\text { Decision Rule (reject } \mathrm{H} 3 \text { if } \mathrm{Z} \text { statistic is } \\
\text { greater than } 1.96 \text { and accept } \mathrm{H} 3 \mathrm{a} \text { ) }\end{array}$ \\
\hline \multirow[t]{2}{*}{$\begin{array}{l}\text { H3: There is no significant influence of the financial } \\
\text { capability to the level of strategic planning }\end{array}$} & & & $\begin{array}{c}\text { Conclusion } \\
\text { Calculated value is } 0.931 \text {, less than } 1.96 \mathrm{z} \text {-statistic }\end{array}$ \\
\hline & $0.351 / 0.377=0.931$ & 1.96 & We accept H3. \\
\hline $\begin{array}{l}\text { H3a: There is a significant influence of the financial } \\
\text { capability to the level of strategic planning }\end{array}$ & & & $\begin{array}{l}\text { There is no significant influence of the financial capability to } \\
\text { Strategic planning in organizations. }\end{array}$ \\
\hline
\end{tabular}


Table 5. Joint effect of managerial skills, financial capability and strategic planning.

\begin{tabular}{cccc}
\hline R & R Square & Adjusted R Square & Sig. F Change \\
\hline $0.634^{\mathrm{a}}$ & 0.402 & 0.375 & 0.000 \\
\hline
\end{tabular}

From the study strategy formulation is a premise of top management but implementation is emphasized in the lower structures. This has far reaching implications for practitioners. Scholars have observed that 40 percent of the planned value does never achieved due to implementation challenges [37] while as [38] posited that strategy implementation was concerned with the design of systems to achieve the best integration of people, structures, processes and resources. Effective strategy implementation is facilitated through action planning, coordination and sys- tems alignment.

Action planning entails assigning responsibilities, indicating timelines, determining expected output and estimating resource requirements that all have to be well coordinated. Reference [39] established that 75 percent of the firms reported ineffective coordination of their strategic actions. Conversely, [38,40] argued that strategy implementation produced capabilities through coordination and integration hence facilitating better performance. Through strategy implementation firms precisely indentify business strengths, weaknesses and specification of existing and potential comparative advantages. This study has reaffirmed the significance of implementation to the strategic planning process in the Ugandan context.

Strategy evaluation is widely undertaken at different levels. This makes the whole process to be moderately recognized across all the levels of management. The level of strategic planning is dependent on many factors. Managers should be able to streamline them and not look at managerial and financial capacity alone. Though the skills of managers and their leadership are key factors in organizations, other environment factors are key dimensions in strategic management.

The whole purpose of strategy is to align organizations with their environment. This study focused on the internal environment factors of managerial and financial capacity; other factors namely policy, size, human resources, facilities and structure could equally count.

While there is growing interest in strategic planning in organizations, managers must assess the contextual factors that influence this activity to inform their decision processes. Strategic planning is an integrated exercise that borrows from several management functions. Managers should be aware of these interactions.

This study has pointed out that financial capability is not a significant predictor of the level of strategic planning but managerial skills are. Even these factors differ across the stages of strategic planning. This finding points to the practical challenge for managers. The need to build a framework for strategic planning does not rely on isolated factors for its success.

We recommend further studies to examine the strategic planning systems and the effect of the external environmental on strategic planning activities in organizations. This study could not have been without some limitations. We took note of the fact that the respondent managers were involved in the study while at the university they were attending a course, this may have had some attendant biased responses. Possibly their responses might have been different if we had approached them individually in their organizations. We also relied on each manager to report about his or her organization of work; we did not extend our investigation to seek alternative views from other senior managers in those organizations neither did we control of the likely event that two or more were working in the same organization. We contend however, that this study has made a contribution to the debate of factors influencing strategic planning especially in the context of less developed countries.

\section{REFERENCES}

[1] V. A. Bagire and J. M. Namada, "Strategic Management in Africa: Tracing Gaps in Sustainable Business Development," Journal of Marketing Management and Competitiveness, Vol. 5, No. 7, 2011, pp. 72-80.

[2] F. Reiner and C. Kazem, "Strategy Development: Past, Present and Future," Training for Quality Journal, Vol. 5, No. 2, 1997, pp. 58-70. doi:10.1108/09684879710167647

[3] H. Mintzberg, "Crafting Strategy," Harvard Business Review, 1987, in Mintzberg Henry. "The Design School: Reconsidering the Basic Premises of Strategic Management," Strategic Management Journal, Vol. 11. 1990, pp. 171-195. doi: $10.1002 / \mathrm{smj} .4250110302$

[4] E. M. Porter, "The Contributions of Industrial Organisation to Strategic, Management," Academy of Management Review, Vol. 6. No. 4, 1981, pp. 609-620.

[5] G. Johnson and K. Scholes, "Exploring Corporate Strategy," Pearson Education Limited, Harlow, 2006.

[6] J. S. Armstrong, "The Value of Strategic Planning for Strategic Decisions: Review of Empirical Research," Strategic Management Journal, Vol. 3, No. 3, 1982, pp. 197-211. doi:10.1002/smj.4250030303

[7] A. C. Hax and S. N. Majluf, "The Corporate Strategic Planning Process," Interfaces, Vol. 14, No. 1, 1984, pp. 47-60. doi:10.1287/inte.14.1.47

[8] M. R. Hunt and P. J. Brews, "Learning to Plan and Planning to Learn: Resolving the Planning School/Learning School Debate," Strategic Management Journal, Vol. 20, No. 10, 1999, pp. 889-913. doi:10.1002/(SICI)1097-0266(199910)20:10<889::AID-S MJ60>3.0.CO;2-F

[9] G. Johnson and K. Scholes, "Exploring Corporate Strategy," 5th Edition, Prentice Hall, London, 1999. 
[10] T. A. Ngwana, "Higher Education Strategic Planning in Sub-Saharan Africa, A Case Study of Cameroon," Education Resource Information Center, Processing and Reference Facility, Lanham, 2002. www.http/ericfacility.org

[11] D. Jemison, "The Contributions of Administrative Behaviour to Strategic Management," Academy of Management Review, Vol. 6. No. 4. 1981, pp. 633-642.

[12] G. Giovani and J. W. Rivikin, "On the Origin of Strategy: Action and Cognition," Organization Science, Vol. 18, No. 3, 2007, pp. 420-439. doi:10.1287/orsc.1070.0282

[13] S. Scott, "Strategy Formulation Methodologies," Center for Information Systems Research, Sloan School of Management, Massachusetts Institute of Technology, 2009. http//dspace.mit.edu

[14] M. Dodgson, "What Role for Management in Science?" Technology Analysis \& Strategic Management, Vol. 11, No. 2, 1999, pp. 133-141. doi:10.1080/095373299107465

[15] E. P. Learned, C. R. Cristensen, K. R. Andrews and W. D. Guth, "Business Policy: Text and Cases," Irwin, Homewood, 1965.

[16] Haspelagh, "Formal Portfolio Planning as a Strategic Management Tool in Diversified Industrial Companies," DBA Dissertation, Harvard. In Bower L. Joseph, "Business Policy in the 1980s," Academy of Management Review, Vol. 7, No. 4, 1981, pp. 630-638.

[17] R. E. White, "Structural Context, Strategy and performance," DBA Dissertation, Harvard. In Bower L. Joseph, "Business Policy in the 1980s," Academy of Management, Review, Vol. 7, No. 4, 1981, pp. 630-638.

[18] W. E. Billi, Berger and B. Hatcher, "A Guidebook to Strategy Evaluation," Southern California Injury Prevention Research Center, Los Angeles, 2009. www.ph.ucla.educ

[19] P. R. Rumelt, "Note on Strategy Evaluation," The Anderson School at UCLA, Anderson, 2000.

[20] R. Kaplan and D. Norton, "The Balanced Score Card, Measures that Drive Performance," Harvard Business Review, 1992. www.12manage.com/methods

[21] S. Nadkarni and P. S. Barr, "Environment Context, Managerial Cognition, and Strategic Action: An Integrated View," Strategic Management Journal, Vol. 29, No. 13, 2008, pp. 1395-1427. doi:10.1002/smj.717

[22] C. K. Prahalad and G. Hamel, "Strategy as a Field of Study: Why Search for a New Paradigm?" Strategic Management Journal, Vol. 15, Suppl. 2, 1994, pp. 5-16. doi:10.1002/smj.4250151002

[23] S. Finkelstein and R. C. Hambrick, "Top-ManagementTeam Tenure and Organizational Outcomes: The Moderating Role of Managerial Discretion," Administrative Science Quarterly, Vol. 35, No. 3, 1990, pp. 484-503. doi: $10.2307 / 2393314$

[24] C. Hambrick and P. A. Mason, "Upper Echelons: The Organisation as a Reflection of Its Top Managers," Academy of Management Review, Vol. 9, No. 2, 1984, pp. 193-206.

[25] R. Rumelt, "Setting Strategy in the New Era," The McKinsey Quarterly, 2009.
[26] F. Olivier, T. Howard and A. Goussevskaia, "The Structure and, Evolution of the Strategic Management Field: A Content Analysis of 26 Years of Strategic Management Research," International Journal of Management Reviews, Vol. 10, No. 1, 2008, pp. 1-23.

[27] D. G. Hoopes, J. L. Madsen and G. Walker, "Guest Editors' Introduction to the Special Issue: Why Is There a Resource Based View? Toward a Theory of Competitive Heterogeneity," Strategic Management Journal, Vol. 24, No. 10, 2003, pp. 889-902. doi:10.1002/smj.356

[28] P. H. Antoniou and H. I. Ansoff, "Strategic Management of Technology," Technology Analysis \& Strategic Management, Vol. 16. No. 2, 2004, pp. 275-291. doi:10.1080/09537320410001682928

[29] R. Muralidharan, "A Framework for Designing Strategy Content Controls," International Journal of Productivity and Performance Management, Vol. 53, No. 7, 2004, pp. 590-601. doi:10.1108/17410400410561213

[30] A. Wong, F. Long and S. Elankumaran, "Business Students' Perception of Corporate Social Responsibility: The United States, China and India," Corporate Social Responsibility and Environmental Management, Vol. 17, No. 5, 2009, pp. 299-310. doi:10.1002/csr.216

[31] O. W. Hill, R. A. Block and S. E. Buggie, "Culture and Beliefs about Time: Comparisons among Black Americans, Black Africans and White Americans," The Journal of Psychology, Vol. 134 No. 4. 2000, pp. 443-461. doi: $10.1080 / 00223980009598228$

[32] J. E. Bartlett, J. W. Kotrlik and C. C. Higgins, "Organizational Research: Determining Appropriate Sample Size in Survey Research," Information Technology, Learning, and Performance Journal, Vol. 19, No. 1, 2001, pp. 4350.

[33] I. H. Ansoff, "Strategic Management," New York, Macmillan, 2007. P. H. Antoniou and H. I. Ansoff, "Strategic Management of Technology," Technology Analysis \& Strategic Management, Vol. 16, No. 2, 2004, pp. 275291.

[34] S. Elbanna, "Planning and Participation as Determinants of Strategic Planning Effectiveness, Evidence from Arabic Context," Management Decisions, Vol. 46, No. 5, 2008, pp. 779-796. doi:10.1108/00251740810873761

[35] J. R. Falshaw, K. W. Glasiter and E. Tatoglu, "Evidence on Formal Strategic Planning and Company Performance," Management Decision, Vol. 44, No. 1, 2006, pp. 9-30. doi:10.1108/00251740610641436

[36] M. Ketokivi and X. Gastner, "Strategic Planning as an Integrative Device," Administrative Science Quarterly, Vol. 49, 2004, pp. 337-365.

[37] M. Mankins and R. Steele, "Turning Great Strategy into Great Performance," Harvard Business Review, Vol. 83 No. 7, 2005, pp. 65-72.

[38] G. A. Ogbeide and J. R. Harrington, "The Relationship among Participative Management Styles, Strategy Implementation and Performance in Service Industry," International Journal of Hospitality Management, Vol. 23 No. 6, 2011, pp. 719-738.

[39] S. M. Ghamdi, "Use of Strategic Planning Tools and 
Techniques in Saudi Arabia; An Empirical Study," International Journal of Management, Vol. 22 No. 2, 2005, pp. $376-395$

[40] O. F. Bustinza, L. M. Molina and D. A. Aranda, “Organ- izational Learning and Performance; Relationship between the Dynamic and Operational Capabilities of the Firm," African Journal of Business Management, Vol. 4 No. 18,2010 , pp. 4067-4078. 